\title{
MAIN WAYS OF FORMING THE READYNESS OF FUTURE TEACHERS FOR ENVIRONMENTAL ACTIVITY
}

\author{
Inna Stakhova \\ Assistant at the Department of Preschool and Primary Education, \\ Vinnytsia Mykhailo Kotsiubynskyi State Pedagogical University, Ukraine \\ e-mail: Kachayloinna@gmail.com,orcid.org/0000-0002-8942-6248
}

\section{Summary}

The article actualizes the problems of anthropogenic impact on the natural environment, determines the need not only to actively act for the nature protection, but also to form an ecologically appropriate behavior of the population, to develop a panoramic environmental outlook. International environmental agreements not only provide for effective steps in the environmental field, but also for progressive education and propaganda of environmental activities. Therefore, we emphasize the importance of training future teachers to organize environmental activities in the process of working with primary school students. In the article, we have revealed the main ways of forming the readiness of future teachers for environmental activities during their training in a higher educational institution, namely, during in-class time (lectures, practical, laboratory), extracurricular activities (club activities, environmental paths, environmental activities, relays, tournaments, boomerangs, quizzes, cruises of an environmental nature), individual work, and pedagogical practice. Special emphasis is placed on the forms that contribute to the formation of students' readiness for environmental activities, the use of various pedagogical technologies. We have given examples of various classes, presented our own experience of organizing club activities in the disciplines of the natural cycle, the ecological paths.

Keywords: environmental activities, in-class time, extracurricular activities, individual work, pedagogical practice.

\section{DOI: https://doi.org/10.23856/4023}

\section{Introduction}

One of the main tasks of humanity is to overcome the environmental crisis caused by anthropogenic impact, to protect and restore the natural environment for normal life, preserving the health of the world's population at the current stage of development and for descendants. That is why today much attention is paid to the formation of readiness of future teachers for environmental activities in primary schools, as it impacts the ability of younger schoolchildren (and in the future, the population of the Earth) to worry, protect, restore the natural environment, to perform responsibly and meaningfully, to consider the consequences of their activities, ensuring a harmonious balance in the "human - nature" system. The need to preserve an ecologically balanced environment is highlighted in a number of world and international conferences and summits (Conference on Sustainable Development, Agenda 21, the UNECE Strategy for Education for Sustainable Development (ESD), Tbilisi +35 Intergovernmental Conference on Environmental Education for Sustainable Development, etc.), the decisions of which are signed or ratified by Ukraine. In modern EU documents (Commission staff working document, Accompanying the document Proposal for a Council recommendation on Key Competences for Life Long Learning, The European Qualifications Framework, Rethinking Education) it 
is important to acquire the key competences for each individual, among which environmental activities. The importance of preserving an ecologically balanced environment and public participation in environmental protection activities is presented in our country's regulatory documents: the Constitution of Ukraine, the Law "On Environmental Protection", the Law "On the Nature Reserve Fund of Ukraine”, the Concept of Environmental Education, etc.

The priorities of our state are related to the formation of readiness of future teachers for environmental protection activities outlined in the Constitution of Ukraine, the Laws of Ukraine "On Education", "On Higher Education", the Concept of a New Ukrainian School, the State standard of Primary Education. A retrospective analysis of the scientific psychological and pedagogical literature shows that the issues of formation of readiness for environmental protection were addressed by leading domestic (T. Baibara, O. Hryhorovych, K. Huz, V. Ilchenko, S. Sovhira, L. Shapoval) and foreign (L. Berényi, A. Varga, J. Gauzere, S. Delzon, H. Davi, M. Bonhomme, I. Garcia de Cortazar-Atauri, I. Chuine) scientists.

\section{Organization of in-class time for future teachers from the cycle of natural science disciplines}

A. Varga (2006) analyzes environmental activities in accordance with environmental competence and other competencies recognized in the EU, because it is impossible to express one's ideas, either orally or in writing, without the competence of communication. Mathematical and scientific competences are necessary because there are natural and mechanical processes and events against the background of environmental pollution and the problems that arise in this regard (Varga, 2006: 3). L. Berényi (2010) agrees with A. Varga on the issue that environmental protection as part of environmental competence is a horizontal competence and should be integrated into all areas of activity. The formation of environmental competence of citizens requires the cooperation of various sciences and industries. The formation of readiness of future primary school teachers for environmental protection activities is carried out during in-class time, extracurricular classes, pedagogical practice and individual work. The author focuses on the importance of environmental competence for citizens of any country (Berényi, 2010: 5). In a scientific article J. Gauzere, S. Delzon, H. Davi, M. Bonhomme, I. Garcia de Cortazar-Atauri, I. Chuine (2017) determine the goal of environmental education enabling everyone to strive for and achieve a greener lifestyle. Scientists begin by distinguishing three forms of environmental knowledge and go on to predict that people's attitude toward nature represents the force that drives their ecological behavioral engagement (Gauzere, Delzon, Davi, Bonhomme, Garcia de Cortazar-Atauri, Chuine: 2017, 9).

In-class time include lectures, practical classes, and laboratory classes. Lecture is one of the forms of training process of future teachers, the so-called type of scientific communication between the teacher and students, which ensures the transfer of the main theoretical provisions (Machynska, Stelmakh, 2012: 76). A lecture has the following structural components: theme, goal, plan, main and additional literature, links to Internet resources. In their works, N. Machynska and S. Stelmakh classify lectures according to the following characteristics: by main purpose: educational, trainning, disciplinary, developmental, agitation; by scientific level: academic and popular; by didactic tasks: introductory, review, current, generalizing, final, consultation lectures, visualization lectures; by method of presentation of the material: binary, lectures-discussions, problem lectures, lectures-conferences (Machynska, Stelmakh, 2012: 78). In our opinion, all the proposed types of lectures are appropriate and necessary in the process of forming the readiness of future teachers for environmental activities. Non-traditional forms 
of presentation of lecture material contribute to the development of logical, critical and creative thinking of future teachers, allow them to see the environmental problem from all aspects and design the most successful way to solve it.

The "flipped classroom" strategy deserves special attention in the process of forming the readiness of future teachers for environmental activities. This is a typical model for European higher education institutions, in which presentation of lecture material and organization of individual homework are reversely arranged. The strategy is that future teachers watch short video lectures at home, whereas during the classroom sessions, they are given time to discuss incomprehensible concepts, do exercises, etc. Video lectures are a key component in the "flipped class" strategy, they are created on the Internet or on a specific online platform (Machynska, Stelmakh, 2012: 92). Practical classes are also used in the process of professional training of future teachers, which are a form of training and involve the study of theoretical issues of the discipline, as well as the formation of practical skills and professional competencies by performing the tasks provided for in the lesson plan. For effective organization of practical training, it is appropriate to use interactive learning technologies. Interactive technologies are based on technologies of cooperative learning, technologies of collective and group activity, technologies of situated modeling, technologies for processing discussion questions. S. Honcharenko attaches great importance to laboratory classes and considers them mandatory, because they are provided for in the curriculum and are aimed at developing students' practical skills and skills to work with the necessary devices, tools, materials, units, and technical means (Honcharenko, 1997: 154).

During laboratory classes, students are invited to participate in phenological observations, excursions to the park, forests, reservoirs, fields, as well as together visit botanical gardens, zoos, planetariums, arboretums; visits to centers for young naturalists, nature museums, seeing works of art that reveal the beauty and richness of nature at various exhibitions, philharmonic halls, theaters will be useful and developing. Excursion classes not only help to deepen knowledge, develop practical skills, but also to consolidate the formation of a holistic image of nature.

\section{Organization of extracurricular activities for future teachers from the cycle of natural science disciplines}

In the process of preparing future primary school teachers for environmental protection, it is also important to use extracurricular activities. One of the leading forms of extracurricular work of students is club activity. According to I. Androshchuk (2014), a club consists of a group of people who are united by a common hobby and activity to generalize knowledge and skills from different industries (Androshchuk, 2014: 122). In our opinion, the club activity of future teachers in natural science disciplines should be aimed at forming their readiness for environmental activities in primary schools through various forms. Thus, in Valentyna Voloshyna Preschool and Primary Education and Arts Department of Vinnytsia Mykhailo Kotsiubynskyi State Pedagogical University there is a student natural science club "Ecosvit" led by us, whose main task is to prepare future teachers of preschool education institutions and future primary school teachers to use innovative technologies in environmental and natural education of preschool children and younger schoolchildren." The following divisions work within the club: "Eureka" research laboratory (conducting interesting tests, scientific experiments); "STORY" studio (making stories, fairy tales; creating cartoons; printed products); "Web-nature" interactive school (developing web-quests, creating a padlet, a natural blog, electronic manuals, 
developing game platforms); "Flash Fashion Nature" workshop of creative biodesign (creating biodesigners' projects, design of flowerbeds, plots); "Smile" playground (developing didactic games, eco-quests, game projects, eco-leagues, eco-comics); "Original Tale-book" workshop of the didactic manual (development and production of didactic materials). Working with future teachers, it is appropriate to offer them participation in clubs such as "Photonaturalists", "Nature, Fantasy, Creativity", "Plants - Symbols of Ukraine”, "Ecoleader", "Ecology for Primary Schoolchildren", etc.

In the process of organizing extracurricular work of future teachers in natural science disciplines, environmental actions are also used, such as "Give a Helping Hand to the Planet", "Clean Shores", "ECO Work Party", "Clean City - Our City", "My Tree", "ECO LIFE", "No Homeless Animals", "Forest are the Lungs of the Planet". An environmental campaign requires painstaking preliminary work. Students need to identify an environmental problem, collect as much information as possible, make arguments, think of ways to solve it, and involve the public in its solution (prepare and distribute leaflets, banners, make announcements in the newspaper or on television). Primary schoolchildren can be involved in conducting an environmental campaign by students. Together, they may prepare speeches, prepare booklets or environmental signs. This activity helps to think about one's own behavior in the natural environment, encourages empathy towards it.

One of the leading forms of extracurricular environmental work of future teachers is the organization of educational trails. A research by N. Oshurkevych proves that the educational trail is an element of the ecological developing environment that should be present in educational institutions, it is identified in a pedagogically organized route by specially defined stations, where one can get acquainted with various natural objects, learn about their uniqueness, value as an integral component of the environment (Oshurkevych, 2018: 3). During the educational trail, a humane attitude to the environment is formed, students learn to feel nature at an internal spiritual level and show their careful, caring attitude. The analysis of scientific literature allows us to conclude that an educational trail is a specially prepared and equipped route that passes through certain natural objects (forests, parks, reservoirs, meadows, botanical gardens, zoos; architectural structures, museums, theaters, whose activities are aimed at protecting and preserving nature). To organize an educational trail, it is necessary to: define the theme and purpose, the venue previously inspected, and if necessary, coordinate the activity with the authorities; make passport of the educational trail with clearly defined stops on the route and the necessary tasks for each of them; prepare a map of educational trail; equip the trail with appropriate signs and tools; conduct an educational trail; discuss and determine successful points and mistakes, what other educational trails students would like to take part in.

During the research, we conducted an educational trail "Step Forward Nature" among students of Valentyna Voloshyna Preschool and Primary Education and Arts Department of Vinnytsia Mykhailo Kotsiubynskyi State Pedagogical University. The purpose of the educational trail was to deepen students' knowledge about changes in the animate and inanimate nature that occur in spring; to form methodological knowledge and skills in organizing observations, holidays, plastic sketches of environmental nature in the process of working with younger schoolchildren. During the educational trail, future teachers passed the following stations: "Forest Glade" (demonstration of a plastic sketch how nature meets spring); "Sky Office" (observation of the sky, determining the type of cloud clusters, shadow orientation); "Flower Alley" (drawing up a passport of flowers, their classification, participation in environmental activities of primroses); "Bird fair" (drawing up a passport of birds, organizing a "bird canteen"); "Nature Conservationist" (students initiation into ecologists). In our opinion, interesting 
and useful topics of educational trails can be "Nature is Our Home", "Save Primroses", "Protect the Forest", "We are the Guardians of Nature", "Beauty Around Us" and so on.

Non-traditional ways of forming the readiness of future teachers for environmental activities include an environmental relay race, an environmental tournament, an environmental boomerang, an environmental quiz, that is, various types of competitions that consist of a set of tasks to be performed by participants, and work on the next task only begins after the previous one is completed.

\section{Organization of individual work of students in the process of forming their readiness for environmental protection activities}

In addition to classroom and extracurricular activities, individual work is important in the process of forming the readiness of future teachers for environmental activities. It contributes to the methodological training of teachers, namely: mastering fundamental theoretical knowledge, activating cognitive activity, understanding cause-and-effect relationships and dependencies, consolidating the main theoretical material and forming the ability to apply it in practice, responsibility in making their own decisions (Kobernik, 2010: 333). Organization of individual work of future teachers is a complex analytical and synthetic education based on a combination of independent theoretical training and formation of practical skills of cognitive activity (Kobernik, 2010: 336). Tasks for individual work of future teachers from the cycle of natural disciplines and methods of teaching natural science in primary school should be aimed at formation of pedagogical, natural and environmental competencies, as well as formulate the goal of their individual activities, evaluate the final and intermediate results of their actions; achieve a high level of development of analytical processes and personal self-regulation, be distinguished by deep self-awareness, adequate self-esteem, strive for self-development and self-improvement (Shyshkina, 2002: 144). In our opinion, for the efficient organization of individual work of students on the cycle of natural scientific disciplines with the purpose of formation of their readiness for environmental activities, it is necessary to: provide future teachers with a complex of textbooks and manuals; create an electronic resource that contains tasks for individual work and necessary list of the literature: primary sources, academic articles, prepared lessons and extracurricular activities, links to Internet resources with teaching materials, best teaching experience, scientific papers, methodical recommendations, etc.; offer differentiated and diverse system tasks, involve students in creative activities; apply interactive methods and techniques during the presentation of tasks for individual activities; offer tasks for pair, group and frontal activities; implement a system of group control, self-control as a means to stimulate self-education of future teachers.

\section{Pedagogical practice in primary schools as a means of forming readiness for environmental protection activities}

An integral part of formation of students' readiness for environmental protection activities is pedagogical practice which, according to H. Kit (2007), "transforms theoretically acquired knowledge of future teachers into necessary practical skills". The researcher defines pedagogical practice as a long, complex and multifunctional process carried out at a higher education institution (Kit, 2007: 5). Future teachers practice in primary schools and gradually join the educational process of younger schoolchildren. Students have morning meetings on natural subjects, first involving fragments, and then whole lessons of natural science (I explore the 
world), together with schoolchildren conduct phenological observations, short and long-term experiments, follow the work in a wildlife corner, organize excursions to nature, environmental campaigns, spend minutes of nature admiring, aesthetic and environmental conversations, are actively involved in the organization of project activities and environmental matters. Thus, pedagogical practice allows future teachers to prepare for a complex and rich educational process in primary school, contributes to deepening and replenishment of the methodological stock in natural disciplines, and forms readiness for environmental activities.

In addition, in the process of studying cycle of natural disciplines, future teachers are involved in field practice in an open area. During the practice, students get a visual representation of the natural world diversity and the processes that occur therein. Future primary school teachers conduct active observations, analyze what they have seen, learn to independently search for connections in the environment, record the facts they have seen and generalize them, and draw their own conclusions. Field practice contributes to a number of tasks in the process of formation of readiness of students to environmental activities in a primary school, namely, deepens, expands and strengthens the knowledge obtained by future teachers in studying a theoretical course; forms methodological skills of carrying out observations in an open area and phenological observations, processing of field data; consolidates practical skills of using devices and equipment for work with natural materials and work in an open area; forms the willingness to perform extra-curricular work in natural science, leadership in environmental clubs, naturalistic work; ingrains respect for nature, extends panoramic environmental outlook and stimulates formation of ecologically appropriate behavior to younger schoolchildren.

\section{Conclusions}

The process of forming the readiness of future teachers for environmental protection activities is very complex and multifaceted; it requires a lot of effort from teachers in organizing and conducting in-class, extracurricular classes, individual work, and pedagogical practice. The formation of readiness for environmental activities will allow students to study more deeply the disciplines of the natural science cycle, acquire environmental competence, develop practical skills, and learn how to organize the educational process of younger schoolchildren methodically. We are convinced that humanely organized environmental activities in primary schools will give an impetus to formation of ecologically appropriate behavior of the population, which in turn will ensure a clean and healthy environment.

Our further research will be aimed at studying the features of forming the readiness of future teachers for environmental activities in primary schools.

\section{References}

Androshchuk, I.V. (2014) Metodyka vykhovnoi roboty [Methods of educational work]. Ternopil: Navchalna knyha. [in Ukrainian]

Berényi, L. (2010) Developing environmental competence Regional Formation and Development Studies. Hungary. [in English]

Gauzere, J., Delzon, S., Davi, H., Bonhomme, M., Garcia de Cortazar-Atauri, I., Chuine, I. (2017) Integrating interactive effects of chilling and photoperiod in phenological process-based models, a case study with two European tree species: Fagus sylvatica and Quercus petraea. Agricultural and Forest Meteorology. [in English] 
Honcharenko, S. (1997) Ukrainskyi pedahohichnyi slovnyk [Ukrainian pedagogical dictionary]. Kyiv: Lybid. [in Ukrainian]

Kit, H.H. (2007) Pedahohichna praktyka u systemi stupenevoi pidhotovky vchytelia pochatkovykh klasiv [Pedagogical practice in the system of degree training of primary school teachers]. Vinnytsia. [in Ukrainian]

Kobernik, S. H. (2010) Naukove obgruntuvannia ta proektuvannia samostiinoi roboty studentiv z metodychnykh dystsyplin pryrodnychoho profiliu $v$ umovakh kredytno-modulnoi systemy navchannia [Scientific substantiation and design of independent work of students in methodical disciplines of a natural profile in the conditions of credit-modular system of training]. Hlukhiv. [in Ukrainian]

Machynska, N.I., Stelmakh S.S. (2012) Suchasni formy orhanizatsii navchalnoho protsesu u vyshchii shkoli [Modern forms of organization of the educational process in higher education]. Lviv: Lvivskyi derzhavnyi universytet vnutrishnikh sprav. [in Ukrainian]

Oshurkevych, N. (2018) Osoblyvosti stvorennia ta vykorystannia ekolohichnoi stezhyny u zakladi doshkilnoi osvity. [Features of creation and use of ecological path in preschool education institution]. Kiev. [in Ukrainian]

Shyshkina, N.O. (2002) Sutnist poniattia ta funktsii samostiinoi roboty studentiv [Features of creation and use of ecological path in preschool education institution]. Kharkiv. [in Ukrainian] Varga, A. (2006) Környezeti kompetenciák fejlesztése tanitási gyakorlatban [Developing Environmental Competences in education practice]. Budapest. [in Hungarian] 